\title{
TOXICITY OF Esenbeckia pumila Pohl (Rutaceae) ON Artemia salina AND Atta sexdens rubropilosa ${ }^{1}$
}

\author{
GEANE KARLA GONÇALVES FERREIRA DUARTE ${ }^{2 *}$, ANTÔNIO CARLOS SEVERO MENEZES ${ }^{2}$, PLÍNIO \\ LÁZARO FALEIRO NAVES ${ }^{2}$, ODAIR CORREA BUENO ${ }^{3}$, RENATO GOMES SANTOS ${ }^{2}$, WEBER MARTINS DA \\ SILVA JUNIOR ${ }^{2}$
}

\begin{abstract}
The number of studies on plant compounds with insecticidal activity has increased in recent years, and one of the primary targets of these compounds is leaf-cutter ants, which are considered the most important pests in Brazilian plantations, especially ants of the genus Atta. The objective of this study was to evaluate the toxic activity of the crude extract and fractions of the leaves of Esenbeckia pumila Pohl (Rutaceae) on Artemia salina and Atta sexdens rubropilosa and to perform a phytochemical study of this plant species. The toxicity of the extract and fractions was evaluated by determining the mean lethal concentration ( $\left.\mathrm{LC}_{50}\right)$ on $A$. salina. The insecticidal activity was evaluated by feeding the ants an artificial diet containing the crude extract or fractions, and the results were analyzed using the log-rank test. The substances were isolated by chromatography, and the molecular structure was determined by spectroscopy. In the bioassay with $A$. salina, the ethanol extract and dichloromethane and ethyl acetate fractions were highly toxic. The analysis of survival curves indicated that the mortality rate of $A$. sexdens rubropilosa workers fed different fractions was higher than that of ants fed the control diet, especially the ethyl acetate fraction, with a mean survival time of 3 days and cumulative mortality of $100 \%$ on day $21(\mathrm{p}<0.05)$. The phytochemical study of this plant species allowed isolating the flavonoid rutin and a mixture of the triterpenes $\alpha$-amyrin, $\beta$-amyrin, and lupeol. These results suggest the insecticidal potential of E. pumila on Atta sexdens rubropilosa.
\end{abstract}

Keywords: Phytochemical study. Natural botanical products. Insecticidal activity.

\section{POTENCIAL TÓXICO DE Esenbeckia pumila Pohl (Rutaceae) SOBRE Artemia salina E Atta sexdens rubropilosa}

RESUMO - A avaliação de moléculas com atividade inseticida provenientes de plantas que apresentam atividade tóxica ou repelente cresceu nos últimos anos, tendo como um dos principais alvos de estudo as formigas cortadeiras, consideradas as principais pragas das plantações brasileiras, especialmente do gênero Atta. Sendo assim, o objetivo deste trabalho foi avaliar o potencial tóxico e inseticida do extrato bruto e frações das folhas de Esenbeckia pumila Pohl (Rutaceae) sobre Artemia salina e Atta sexdens rubropilosa e realizar o estudo fitoquímico daquela espécie. A avaliação da toxicidade do extrato e das frações foi realizada em bioensaio com $A$. salina determinando-se $\mathrm{CL}_{50}$ (Concentração Letal Média). A atividade inseticida foi avaliada pela ingestão do extrato e das frações incorporados a dieta artificial e os resultados foram tratados estatisticamente através do teste log rank. O isolamento de substâncias foi realizado por métodos cromatográficos e as estruturas determinadas pela análise de dados espectroscópicos. No bioensaio contra $A$. salina, o extrato etanólico e as frações diclorometânica e acetato-etílica se mostraram altamente tóxicas. A análise estatística das curvas de sobrevivência revelou taxas de mortalidade significativas de operárias de $A$. sexdens rubropilosa quando comparadas à dieta controle, com destaque para a fração acetato-etílica que apresentou sobrevivência mediana (Md) no $3^{\circ}$ dia e mortalidade de $100 \%$ no $21^{\circ}$ dia $(p<0,05)$. O estudo fitoquímico da espécie levou ao isolamento do flavanoide rutina e de uma mistura dos triterpenos $\alpha$-amirina, $\beta$ amirina e lupeol. Esses resultados sugerem o potencial inseticida de E. pumila sobre Atta sexdens rubropilosa.

Palavras-chave: Estudo fitoquímico. Produtos naturais botânicos. Atividade inseticida.

\footnotetext{
${ }^{*}$ Corresponding author

${ }^{1}$ Received for publication in $11 / 05 / 2017$; accepted in $09 / 26 / 2018$

Paper extracted from the masters dissertation of the first author.

${ }^{2}$ Campus of Exact and Technological Sciences, Universidade Estadual de Goiás, Anápolis, GO, Brazil; geane.k.duarte@gmail.com ORCID: 0000-0002-9392-723X, antonio.menezes@ueg.br - ORCID: 0000-0001-8484-315X, plinionaves@ueg.br - ORCID: 0000-00031936-1837, renato_fsc@hotmail.com - ORCID: 0000-0002-4463-0712, weberjunior38@gmail.com - ORCID: 0000-0001-6539-1434.

${ }^{3}$ Department of Biology and Technological Sciences, Universidade Estadual Paulista, Rio Claro, SP, Brazil; odaircb@rc.unesp.br ORCID: 0000-0002-3586-6192.
} 


\section{INTRODUCTION}

The study of plant toxicity is essential for two main reasons. The first reason is understanding the toxic potential of medicinal and ornamental plant species to avoid cases of intoxication, and the second reason regards the close relationship between toxicity and biological activity may lead to the identification of substances with pharmacological properties (CAMPOS et al., 2016).

Meyer et al. (1982) have suggested that Artemia salina Leach, 1819 (Anostraca: Artemiidae) is useful for determining the pharmacological activity of plant extracts by evaluating their toxicity against newly hatched nauplii. The lethality bioassay in A. salina is routinely used in the research of natural products, and several studies demonstrated the correlation between toxicity against $A$. salina and the biological activity of these substances, including antitumor (ALBUQUERQUE et al., 2014), antifungal (LEITE et al., 2009), antibacterial (APU et al., 2010), and insecticidal (NISAR et al., 2015).

The search for new plant compounds with insecticidal activity has increased in recent years, mainly because of the presumed safety of these compounds to humans and the environment (DELLA LUCIA; GANDRA; GUEDES, 2014). In Brazil, the search for active compounds against leaf-cutting ants, which are considered the main pests of Brazilian plantations, especially ants of the genus Atta, causes significant economic losses to agricultural and reforestation areas (ZANETTI et al., 2014).

Several plant species, including some belonging to the Rutaceae family, are active against Atta sexdens rubropilosa Forel, 1908 (Hymenoptera: Formicidae), including Spiranthera odoratissima A. St.-Hil (TEREZAN et al., 2010), Heliettapuberula RE Fr. (ALMEIDA et al., 2007), Raulinoa echinata Cowan (BIAVATTI et al., 2005), and Citrus limon (L.) Burm (FERNANDES et al., 2002). Esenbeckia grandiflora Mart is active against Atta sexdens sexdens Lineu, 1758 (GOMES et al., 2016).

The Rutaceae family contains several secondary metabolites, especially coumarins, alkaloids, triterpenes, limonoids, and flavonoids (COY-BARRERA; CUCA-SUÁREZ; LONDOÑO, 2013), and many of these metabolites have biological activity, including larvicidal (MUKANDIWA; ELOFF; NAIDOO, 2015), antibacterial (BITCHAGNO et al., 2015; CUCA-SUÁREZ et al., 2011; KUETE et al., 2008), and antiplasmodial (MUGANGA et al., 2014) activity.

Esenbeckia is a genus with antileishmanial (NAPOLITANO et al., 2004), anticholinesterase (CARDOSO-LOPES et al., 2010), and antimalarial (DOLABELA et al., 2008) activity. Kubo, Vieira and Fukuhara (1990) found that the methanol extract of leaves of Esenbeckia pumila Pohl (1826), a bush with a height of approximately 1 meter for which literature data on its popular use are scarce, inhibited the growth of the tobacco caterpillar (Heliothis virescens Fabricius, 1781) and the pink bollworm (Pectinophora gossypiella Saunders, 1843).

The objective of this study was to evaluate the toxic activity of the raw extract and fractions of the leaves of Esenbeckia pumila Pohl (Rutaceae) on Artemia salina and Atta sexdens rubropilosa and perform a phytochemical study of this plant species.

\section{MATERIAL AND METHODS}

\section{Plant samples}

The leaves of E. pumila plants were collected in May 2015 at the Anápolis Campus of Exact and Technological Sciences, State University of Goiás (Universidade Estadual de Goiás-UEG). The species were identified by Professor Mirley Luciene dos Santos, and exsiccates were deposited at the UEG Herbarium under Exsiccate No. 10883.

\section{Processing of plant extract and fractions}

The specimens were oven dried at $45{ }^{\circ} \mathrm{C}$ under air circulation for 48 hours and milled in a Willey mill. The pulverized material was subjected to extraction by cold maceration with $96 \%$ ethanol. The obtained ethanol extract was filtered and concentrated in a rotary evaporator (MATOS, 2009).

The ethanol extract (EE) of leaves was fractionated using solvents with increasing polarity (hexane, dichloromethane, ethyl acetate, and methanol). This process was carried out by vacuum filtration after the incorporation of microcrystalline cellulose D to the EE. Four fractions were obtained: hexane fraction (HF), dichloromethane fraction (DF), ethyl acetate fraction (EAF), and methanol fraction (MF).

\section{Toxicity tests on Artemia salina}

This test was based on the method described by Meyer et al. (1982) and adapted by MolinaSalinas and Said-Fernández (2006) and consisted in exposing A. salina nauplii to five concentrations of the extract and fractions of E. pumila and measurement of the mean lethal concentration $\left(\mathrm{LC}_{50}\right)$.

For this purpose, commercial A. salina cysts (25 mg) were incubated at $20-25{ }^{\circ} \mathrm{C}$ in artificial seawater prepared with sea salt $\left(48 \mathrm{~g} \mathrm{~L} \mathrm{~L}^{-1}\right)$ and distilled water and supplemented with yeast extract $\left(6 \mathrm{~g} \mathrm{~L}^{-1}\right)$, and the $\mathrm{pH}$ was adjusted to 8.5 with 0.1 mol L-1 $\mathrm{Na}_{2} \mathrm{CO}_{3}$ solution. After the cysts hatched, the released nauplii were collected by attracting them to a light source and transferring them to Petri dishes containing fresh saline medium. The collected nauplii were transferred to 96-well polystyrene 
microplates $(10 \pm 1$ individuals per well).

The EE, HF, DF, EAF, and MF of E. pumila were diluted in dimethyl sulfoxide (DMSO) and saline to obtain different concentrations $(4000,2000$, $1000,500,250$, and $\left.125 \mathrm{mg} \mathrm{L}^{-1}\right)$. Subsequently, final concentrations of 2000, 100, 500, 250, 125, and 62.5 $\mathrm{mg} \mathrm{L}^{-1}$ were added to the microplate wells containing the microcrustaceans. A well containing $2.5 \%$ DMSO was used as the viability control, and a well containing a potassium dichromate solution was used as the lethality control. The diluent used in both controls was artificial sea water.

After a 24-hour incubation at room temperature under artificial lighting, live and dead nauplii were counted in each assay. Each assay was performed in triplicate. The $\mathrm{LC}_{50}$ values were calculated from the linear regression obtained from the ratio between the percentage of dead nauplii and the extract concentration. For this purpose, PROBIT analysis was conducted using STATPLUS software version 2009

The toxicity of the EE and fractions was determined and classified according to the method presented by Nguta et al. (2011) as follows: LC $_{50}$ $<100 \mathrm{mg} \mathrm{L}^{-1}$, highly toxic; $\mathrm{LC}_{50}$ of $100-500 \mathrm{mg} \mathrm{L}^{-1}$, moderately toxic; $\mathrm{LC}_{50}$ of $500-1000 \mathrm{mg} \mathrm{L}^{-1}$, mildly toxic; and $\mathrm{LC}_{50}>1000 \mathrm{mg} \mathrm{L}^{-1}$, non-toxic (Table 1).

Table 1. Classification of toxicity of the leaves of Esenbeckia pumila to Artemia salina according to Nguta et al. (2011).

\begin{tabular}{cc}
\hline LC $_{50}$ values & Toxicity \\
\hline$<100 \mathrm{mg} \mathrm{L}^{-1}$ & High \\
$100-500 \mathrm{mg} \mathrm{L}^{-1}$ & Moderate \\
$500-1000 \mathrm{mg} \mathrm{L}^{-1}$ & Low \\
$>1000 \mathrm{mg} \mathrm{L}^{-1}$ & Nontoxic \\
\hline
\end{tabular}

$\mathrm{LC}_{50}$, mean lethal concentration.

\section{Bioassay with Atta sexdens rubropilosa}

The assays were performed at the Center for Studies on Social Insects of UNESP, Rio Claro campus, Rio Claro, São Paulo, Brazil. The workers of leaf-cutter ants $A$. sexdens rubropilosa were collected from ant nests maintained in the laboratory with leaves of Eucalyptus sp., oat flakes and other plants palatable to ants, including Hibiscus sp., Ligustrum sp., and rose leaves and petals.

The ants isolated from the nests were fed a solid artificial diet containing $1.25 \mathrm{~g}$ of glucose, 0.25 $\mathrm{g}$ of bacteriological peptone, $0.025 \mathrm{~g}$ of yeast extract, $0.25 \mathrm{~g}$ of bacteriological agar, and $25 \mathrm{~mL}$ of distilled water. The diet was solubilized in a microwave oven, autoclaved for 15 minutes at $120^{\circ} \mathrm{C}$ and $1 \mathrm{~atm}$, and transferred to $10 \mathrm{~cm}$-sterilized Petri dishes. After cooling and solidification, the diet was enclosed in PVC film and kept in the refrigerator for use in the study period (BUENO et al., 1997).

The insecticidal activity was determined by feeding ants a solid artificial diet containing one of three concentrations $(0.2,1.0$, and $2.0 \mathrm{mg})$ of the EE, $\mathrm{HF}$, DF, EAF, or MF of E. pumila. First, these fractions were mixed to glucose and the remaining dry ingredients of the diet and later dissolved in distilled water. The obtained mixture was heated in a microwave oven, solubilized, sterilized, and stored in the same way as the control diet.

For each treatment, the ant workers (body mass of $15-25 \mathrm{mg}$ ) were separated in batches of 50 individuals and transferred to five $10-\mathrm{cm}$ Petri dishes (ten insects per dish) lined with filter paper. The control diet or the diet containing either the EE or one of the fractions (treatments) $(0.4-0.5 \mathrm{~g})$ was transferred to each Petri dish. The dishes were incubated in a BOD oven at $24 \pm 1{ }^{\circ} \mathrm{C}$ and relative humidity of $70-80 \%$. The bioassays were evaluated daily for a maximum period of 25 days to determine the number of dead ants, remove dead ants, feed the ants, and change the filter paper considering the usual survival period of ants fed artificial diets (BUENO et al., 1997).

The cumulative percentages of live ants per day for each treatment were determined. After that, the median survival time (MS) was calculated, and the survival curves of the treatments and control were compared statistically by the non-parametric log-rank test $(\mathrm{p}<0.05) \quad($ ELANDT-JOHNSON; JOHNSON, 1980) using GraphPad Prisma software version 3.0 .

\section{Isolation and identification of plant compounds}

The EAF (11.74 g) was separated by chromatography using a silica gel 60 column (height, $17 \mathrm{~cm}$; diameter, $5 \mathrm{~cm}$ ). The mobile phase was dichloromethane and methanol at increasing concentrations. Seven fractions were obtained. After analyzing the obtained fractions by thin layer chromatography (TLC), the third fraction (Nos. 13$26,608 \mathrm{mg}$ ) was subjected to a new fractionation by chromatography using a silica gel 60 column (height, $11 \mathrm{~cm}$; diameter, $5 \mathrm{~cm}$ ). The mobile phase was hexane and ethyl acetate at increasing concentrations. Eleven fractions were obtained; of 
these, the third fraction (No. 53, $5 \mathrm{mg}$ ), designated EP-1, was characterized by ${ }^{1} \mathrm{H}$ and ${ }^{13} \mathrm{C}$ NMR.

The MF (2.0 g) was subjected to chromatography using a Sephadex LH-20 column (height, $30 \mathrm{~cm}$, diameter, $2 \mathrm{~cm}$ ) and using methanol as the mobile phase. Seven fractions were obtained. After examining the eluted fractions by TLC, the third fraction (Nos. 9-16, $700 \mathrm{mg}$ ) was subjected to a new fractionation by chromatography using a Sephadex LH-20 column (height, $37 \mathrm{~cm}$; diameter, 2 $\mathrm{cm}$ ) and methanol as the mobile phase. Thirteen fractions were obtained. The third fraction of this new fractionation (No. 22; $12 \mathrm{mg}$ ), named EP-3, was characterized by ${ }^{1} \mathrm{H}$ and ${ }^{13} \mathrm{C} \mathrm{NMR}$.

\section{RESULTS AND DISCUSSION}

The toxicity values of all tested compounds, except for MF, were lower than $1000 \mathrm{mg} \mathrm{L}^{-1}$, indicating toxicity to $A$. salina nauplii. According to the classification of Nguta et al. (2011), the EE $\left(\mathrm{CL}_{50}, 64 \mathrm{mg} \mathrm{L}^{-1}\right)$, DF $\left(\mathrm{CL}_{50}, 57 \mathrm{mg} \mathrm{L}^{-1}\right)$, and EAF $\left(\mathrm{CL}_{50}, 65 \mathrm{mg} \mathrm{L}^{-1}\right)$ showed high toxicity whereas the $\mathrm{HF}$ presented moderate toxicity $\left(\mathrm{CL}_{50}, 149 \mathrm{mg} \mathrm{L}^{-1}\right)$, suggesting the potentially high bioactivity of these compounds (Meyer et al., 1982). Fraction MF ( $\mathrm{CL}_{50}$, $1618 \mathrm{mg} \mathrm{L}^{-1}$ ) was not toxic to A. salina, suggesting that it may be well tolerated in biological systems (Table 2).

Table 2. Toxicity of the leaves of Esenbeckia pumila to Artemia salina.

\begin{tabular}{ccc}
\hline Extract and fractions & $\mathrm{CL}_{50}\left(\mathrm{mg} \mathrm{L}^{-1}\right)$ & Toxicity \\
\hline EE & 64 & High \\
DF & 57 & High \\
EAF & 65 & High \\
HF & 149 & Moderate \\
MF & 1618 & None \\
\hline
\end{tabular}

The results obtained in each bioassay with $A$. sexdens rubropilosa are presented as survival curves and tables that summarize the daily cumulative mortality, MS, and the results of the log-rank test.

The survival of ants that ingested $0.2 \mathrm{mg}$ of EE was higher than that of ants from the control group and the other treatments (Figure 1). The MS of ants receiving $0.2,1.0$, and $2.0 \mathrm{mg}$ of the EE was 25 , 17 , and 7 days, respectively, whereas the cumulative mortality at the end of treatment (day 25) at the same concentrations was $44 \%, 68 \%$, and $88 \%$, respectively (Table 3 ).

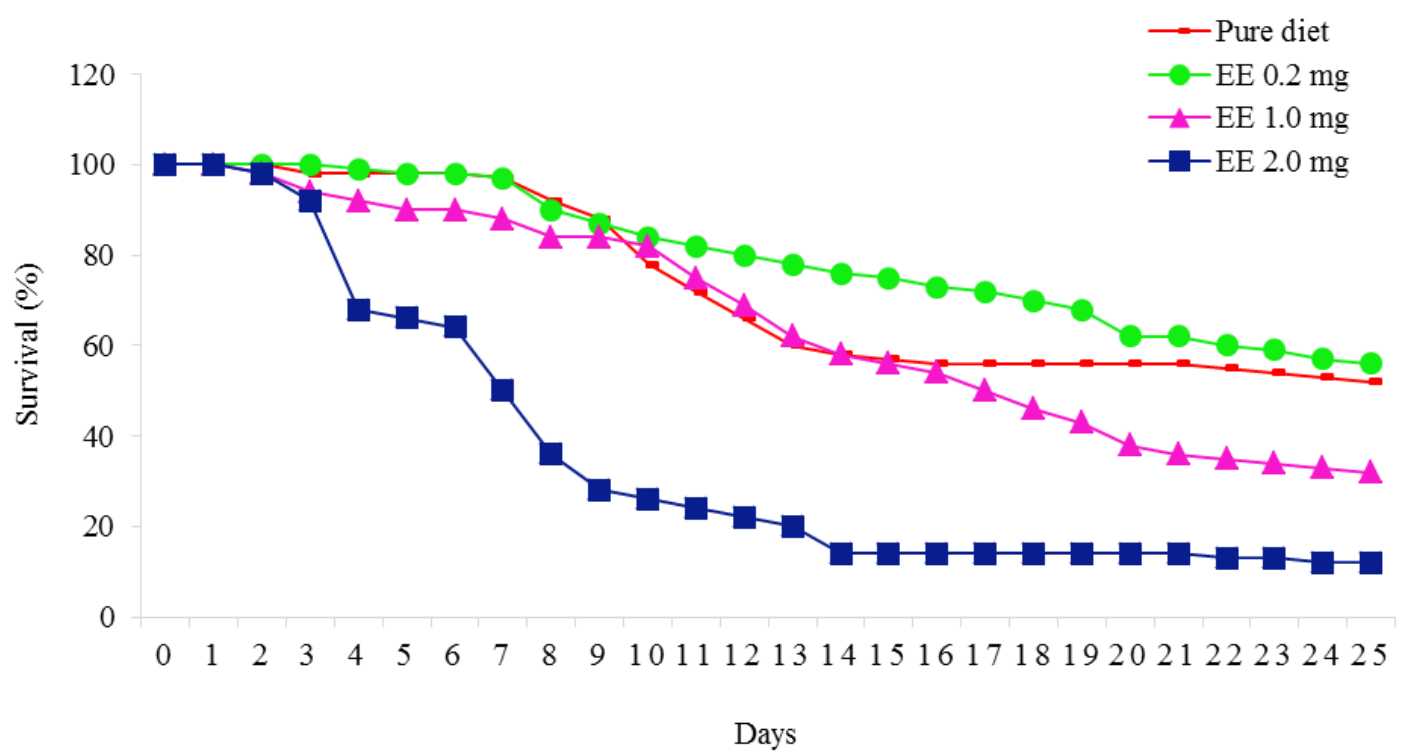

Figure 1. Survival curves of Atta sexdens rubropilosa workers fed an artificial diet containing the ethanol extract (EE) of the leaves of Esenbeckia pumila. 
Table 3. Cumulative mortality and median survival time of Atta sexdens rubropilosa fed an artificial diet containing 0.2 , 1.0 , or $2.0 \mathrm{mg}$ of the ethanol extract of the leaves of Esenbeckia pumila.

\begin{tabular}{|c|c|c|c|c|c|c|c|c|c|c|c|}
\hline \multirow{2}{*}{ Treatment } & \multicolumn{10}{|c|}{ Daily cumulative mortality (\%) } & \multirow{2}{*}{ MS* } \\
\hline & 1 & 2 & 3 & 6 & 8 & 10 & 14 & 17 & 21 & 25 & \\
\hline Pure diet & 0 & 0 & 2 & 2 & 8 & 22 & 42 & 44 & 44 & 48 & $>25 a$ \\
\hline Ethanol extract $(0.2 \mathrm{mg})$ & 0 & 0 & 0 & 2 & 10 & 16 & 24 & 28 & 38 & 44 & $25 a$ \\
\hline Ethanol extract $(1.0 \mathrm{mg})$ & 0 & 2 & 6 & 10 & 16 & 18 & 42 & 50 & 64 & 68 & $17 b$ \\
\hline Ethanol extract $(2.0 \mathrm{mg})$ & 0 & 2 & 8 & 36 & 64 & 74 & 86 & 86 & 86 & 88 & $7 \mathrm{~b}$ \\
\hline
\end{tabular}

Legend: *Different letters relative to the control indicate significant differences using the log-rank test $(\mathrm{p}<0.05)$.

The results indicated that only $0.2 \mathrm{mg}$ of the EE (MS of 25 days) did not present significant toxicity when compared with the pure diet (MS $>25$ days). The EE at $2.0 \mathrm{mg}$ had the highest toxicity (MS of 7 days and cumulative mortality of $88 \%$ at the end of treatment).

The survival curve of the $\mathrm{HF}$ at $1.0 \mathrm{mg}$ indicated a significant difference between this treatment and the others (Figure 2). The curve presented a slope between days 2 and 10 of treatment, corresponding to a $20 \%$ decrease in the number of live workers.

The MS of ants fed $0.2,1.0$, and $2.0 \mathrm{mg}$ of this fraction was 21,8 , and 19 days, respectively, and the cumulative mortality was $56 \%, 92 \%$, and $70 \%$ at the end of treatment, respectively (Table 4).

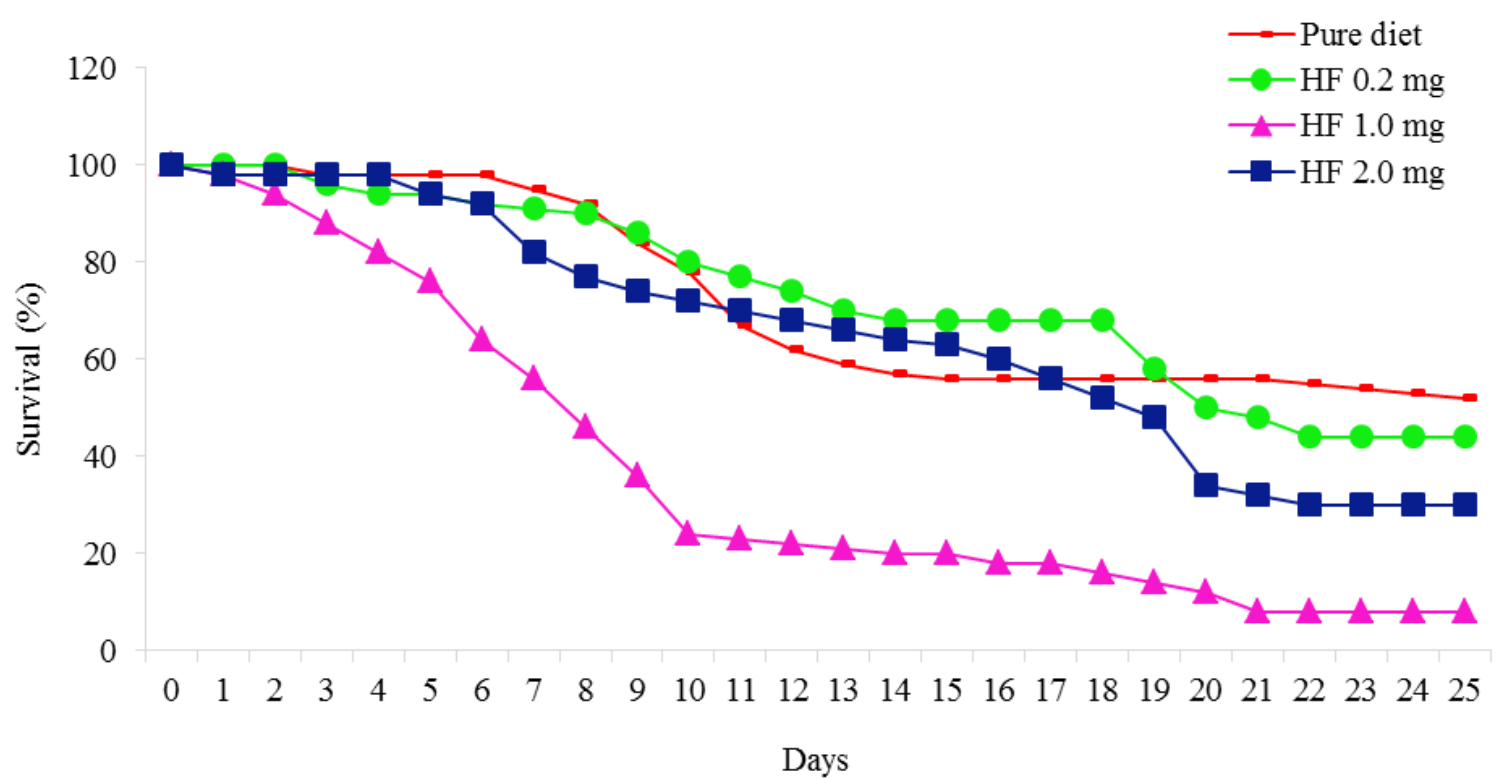

Figure 2. Survival curves of Atta sexdens rubropilosa workers fed an artificial diet containing the hexane fraction (HF) of the leaves of Esenbeckia pumila.

Table 4. Cumulative mortality and median survival time of Atta sexdens rubropilosa fed an artificial diet containing 0.2 , 1.0 , or $2.0 \mathrm{mg}$ of the hexane fraction of the leaves of Esenbeckia pumila.

\begin{tabular}{|c|c|c|c|c|c|c|c|c|c|c|c|}
\hline \multirow{2}{*}{ Treatment } & \multicolumn{10}{|c|}{ Daily cumulative mortality (\%) } & \multirow{2}{*}{ MS* } \\
\hline & 1 & 2 & 3 & 6 & 8 & 10 & 14 & 17 & 21 & 25 & \\
\hline Pure diet & 0 & 0 & 2 & 2 & 8 & 22 & 42 & 44 & 44 & 48 & $>25 a$ \\
\hline $\begin{array}{c}\text { Hexane extract }(0.2 \\
\mathrm{mg})\end{array}$ & 0 & 0 & 4 & 8 & 10 & 20 & 32 & 32 & 52 & 56 & $21 b$ \\
\hline $\begin{array}{c}\text { Hexane extract (1.0 } \\
\mathrm{mg})\end{array}$ & 2 & 6 & 12 & 36 & 54 & 76 & 80 & 82 & 92 & 92 & $8 \mathrm{~b}$ \\
\hline $\begin{array}{c}\text { Hexane extract (2.0 } \\
\mathrm{mg})\end{array}$ & 2 & 2 & 2 & 8 & 22 & 28 & 36 & 44 & 68 & 70 & $19 b$ \\
\hline
\end{tabular}

Legend: *Different letters relative to the control indicate significant differences using the log-rank test $(\mathrm{p}<0.05)$. 
The toxicity results were independent of the concentration because using $1.0 \mathrm{mg}$ of the $\mathrm{HF}, 50 \%$ of the ants died on day 8 after treatment and $92 \%$ died at the end of treatment, indicating higher insecticidal activity, whereas $2.0 \mathrm{mg}$ of the HF killed $50 \%$ of the ants on day 19 and $70 \%$ on day 25 after treatment. These results are promising when considering the potential use of this fraction because a smaller amount of raw material would be necessary to achieve higher toxicity, suggesting that the killing effect observed in these concentrations are not dosedependent.

The survival of leaf-cutting ants was lower using $1.0 \mathrm{mg}$ of the DF compared to the control and the other treatments, and there was a significant reduction in the percentage of live ants between days 2 and 6 (Figure 3).

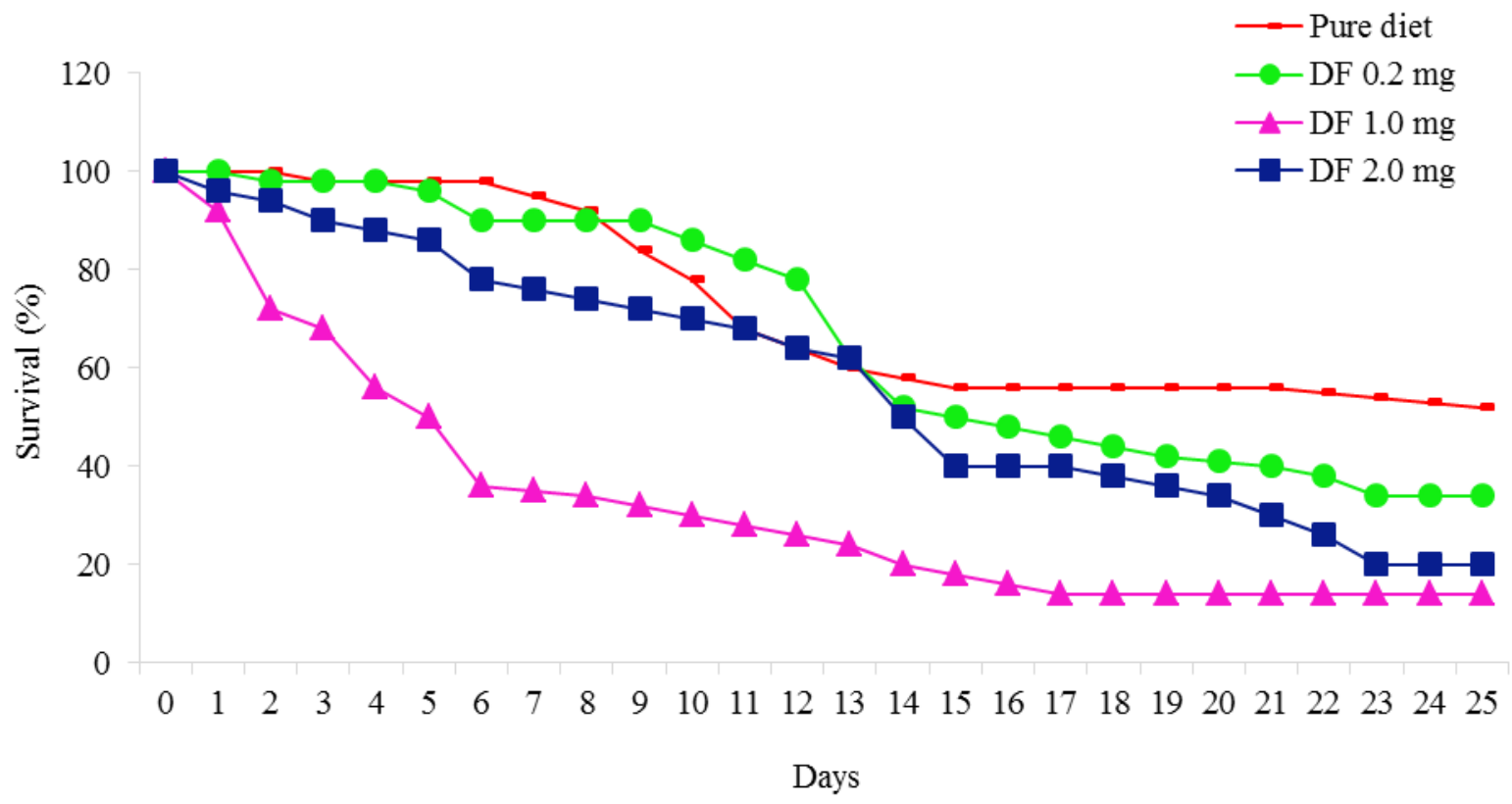

Figure 3. Survival curves of Atta sexdens rubropilosa workers fed an artificial diet containing the dichloromethane fraction (DF) of the leaves of Esenbeckia pumila.

At the concentrations of $0.2,1.0$, and $2.0 \mathrm{mg}$ of the DF, $50 \%$ of the insects were alive on days 15 , 6 , and 14 after treatment, respectively, and the cumulative mortality was $66 \%, 86 \%$, and $80 \%$, respectively (Table 5). These results are similar to those obtained using the HF, although the MS values for the DF were significantly higher: $50 \%$ of the workers were killed on day 6 , and the cumulative mortality was $86 \%$ on day 25 .

Table 5. Cumulative mortality and median survival time of Atta sexdens rubropilosa workers fed an artificial diet containing $0.2,1.0$, or $2.0 \mathrm{mg}$ of the dichloromethane fraction of the leaves of Esenbeckia pumila.

\begin{tabular}{|c|c|c|c|c|c|c|c|c|c|c|c|}
\hline \multirow{2}{*}{ Treatment } & \multicolumn{10}{|c|}{ Daily cumulative mortality (\%) } & \multirow{2}{*}{ MS* } \\
\hline & 1 & 2 & 3 & 6 & 8 & 10 & 14 & 17 & 21 & 25 & \\
\hline Pure diet & 0 & 0 & 2 & 2 & 8 & 22 & 42 & 44 & 44 & 48 & $>25 a$ \\
\hline $\begin{array}{l}\text { Dichloromethane } \\
\text { fraction }(0.2 \mathrm{mg})\end{array}$ & 0 & 2 & 2 & 10 & 10 & 14 & 48 & 54 & 60 & 66 & $15 b$ \\
\hline $\begin{array}{l}\text { Dichloromethane } \\
\text { fraction }(1.0 \mathrm{mg})\end{array}$ & 8 & 28 & 32 & 64 & 66 & 70 & 80 & 86 & 86 & 86 & $6 b$ \\
\hline $\begin{array}{l}\text { Dichloromethane } \\
\text { fraction }(2.0 \mathrm{mg})\end{array}$ & 4 & 6 & 10 & 22 & 26 & 30 & 50 & 60 & 70 & 80 & $14 b$ \\
\hline
\end{tabular}

Legend: *Different letters relative to the control indicate significant differences using the log-rank test $(\mathrm{p}<0.05)$. 
The survival curve of treatment using $2.0 \mathrm{mg}$ of the EAF indicated a significant decrease in the number of live ants from day 1 to day 3, and cumulative survival decreased from $100 \%$ to approximately $20 \%$ in less than 2 days (Figure 4 ).

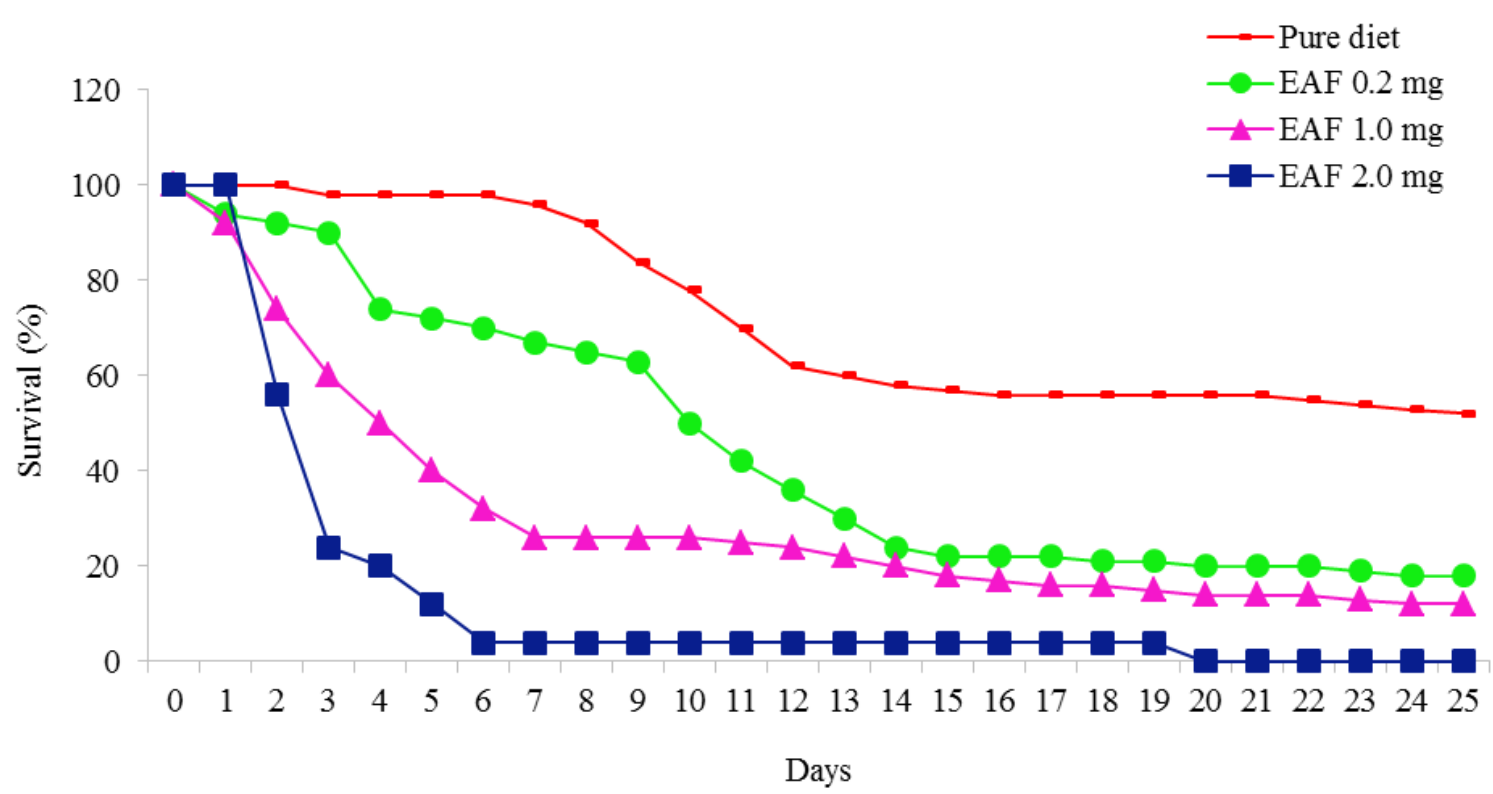

Figure 4. Survival curves of Atta sexdens rubropilosa workers fed an artificial diet containing the ethyl acetate fraction (EAF) of the leaves of Esenbeckia pumila.

The MS of ants fed $0.2,1.0$, or $2.0 \mathrm{mg}$ of the EAF was 10, 4, and 3 days, respectively, and the cumulative mortality was $82 \%, 88 \%$, and $100 \%$, respectively (Table 6). These results are relevant, especially at $2.0 \mathrm{mg}$, for which the MS was 3 days, and the cumulative mortality was $96 \%$ on day 6 and $100 \%$ on day 21 . The MS of ants receiving $0.2 \mathrm{mg}$ of the EAF was 10 days, and the cumulative mortality was $82 \%$ at the end of treatment.

The survival curves at 1.0 and $2.0 \mathrm{mg}$ of the MF almost overlapped from day 10 of treatment; however, $2.0 \mathrm{mg}$ was relatively more effective because it significantly decreased the number of live ants by approximately $20 \%$ on day 3 (Figure 5 ).

Table 6. Cumulative mortality and median survival of Atta sexdens rubropilosa workers fed an artificial diet containing $0.2,1.0$, or $2.0 \mathrm{mg}$ of the ethyl acetate fraction of the leaves of Esenbeckia pumila.

\begin{tabular}{|c|c|c|c|c|c|c|c|c|c|c|c|}
\hline \multirow{2}{*}{ Treatment } & \multicolumn{10}{|c|}{ Daily cumulative mortality (\%) } & \multirow{2}{*}{ MS* } \\
\hline & 1 & 2 & 3 & 6 & 8 & 10 & 14 & 17 & 21 & 25 & \\
\hline Pure diet & 0 & 0 & 2 & 2 & 8 & 22 & 42 & 44 & 44 & 48 & $>25 a$ \\
\hline $\begin{array}{l}\text { Ethyl acetate fraction } \\
\qquad(0.2 \mathrm{mg})\end{array}$ & 6 & 8 & 10 & 30 & 36 & 50 & 76 & 78 & 80 & 82 & $10 b$ \\
\hline $\begin{array}{l}\text { Ethyl acetate fraction } \\
(1.0 \mathrm{mg})\end{array}$ & 8 & 26 & 40 & 68 & 74 & 74 & 80 & 84 & 86 & 88 & $4 b$ \\
\hline $\begin{array}{l}\text { Ethyl acetate fraction } \\
(2.0 \mathrm{mg})\end{array}$ & 0 & 44 & 76 & 96 & 96 & 96 & 96 & 96 & 100 & 100 & $3 b$ \\
\hline
\end{tabular}

Legend: *Different letters relative to the control indicate significant differences using the log-rank test $(\mathrm{p}<0.05)$. 


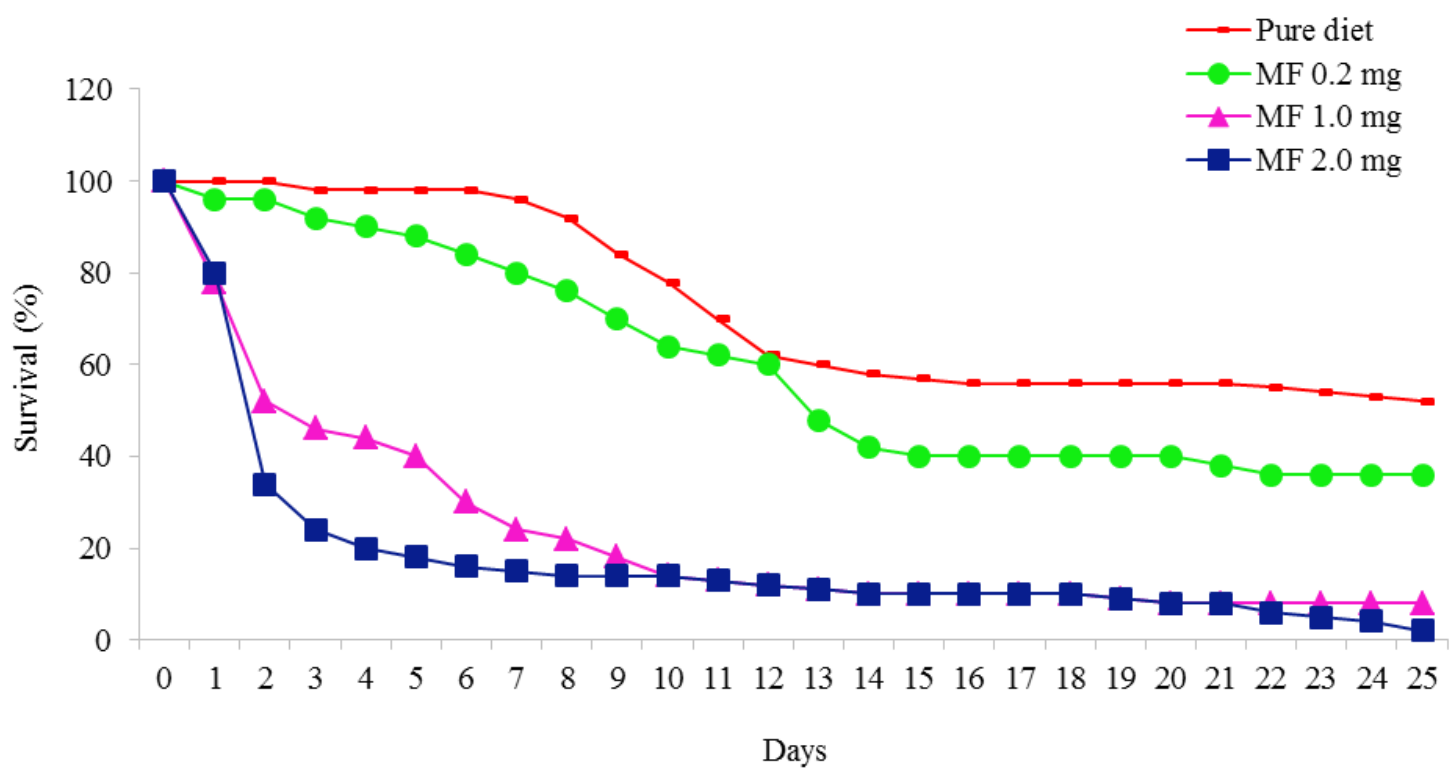

Figure 5. Survival curves of Atta sexdens rubropilosa workers fed an artificial diet containing the methanol fraction (MF) of the leaves of Esenbeckia pumila.

The MS of ants fed $0.2,1.0$, and $2.0 \mathrm{mg}$ of the MF was 13, 3, and 2 days, respectively, and the cumulative mortality was $64 \%, 92 \%$, and $98 \%$, respectively (Table 7).

The comparison of the results with each other indicated that the concentrations of 1.0 and $2.0 \mathrm{mg}$ of this fraction were the most effective, demonstrated by the cumulative mortality of $92 \%$ and $98 \%$ at the end of treatment and MS of 3 and 2 days, respectively. These values were significantly higher than those of the treatment with the control diet.

Table 7. Cumulative mortality and median survival time of Atta sexdens rubropilosa workers fed a diet containing 0.2, 1.0, or $2.0 \mathrm{mg}$ of the methanol fraction of the leaves of Esenbeckia pumila.

\begin{tabular}{|c|c|c|c|c|c|c|c|c|c|c|c|}
\hline \multirow{2}{*}{ Treatment } & \multicolumn{10}{|c|}{ Daily cumulative mortality (\%) } & \multirow{2}{*}{ MS* } \\
\hline & 1 & 2 & 3 & 6 & 8 & 10 & 14 & 17 & 21 & 25 & \\
\hline Pure diet & 0 & 0 & 2 & 2 & 8 & 22 & 42 & 44 & 44 & 48 & $>25 a$ \\
\hline $\begin{array}{l}\text { Methanol fraction }(0.2 \\
\mathrm{mg})\end{array}$ & 4 & 4 & 8 & 16 & 24 & 36 & 58 & 60 & 62 & 64 & $13 b$ \\
\hline $\begin{array}{l}\text { Methanol fraction (1.0 } \\
\mathrm{mg})\end{array}$ & 22 & 48 & 54 & 70 & 78 & 86 & 90 & 90 & 92 & 92 & $3 b$ \\
\hline $\begin{array}{l}\text { Methanol fraction ( } 2.0 \\
\mathrm{mg})\end{array}$ & 20 & 64 & 76 & 84 & 86 & 86 & 90 & 90 & 92 & 98 & $2 b$ \\
\hline
\end{tabular}

Legend: *Different letters relative to the control indicate significant differences using the log-rank test $(\mathrm{p}<0.05)$.

The comparison of the results with each other indicated that the concentrations of 1.0 and $2.0 \mathrm{mg}$ of this fraction were the most effective, demonstrated by the cumulative mortality of $92 \%$ and $98 \%$ at the end of treatment and MS of 3 and 2 days, respectively. These values were significantly higher than those of the treatment with the control diet.

All tested concentrations of the EE, HF, DF, EAF, and MF significantly decreased the survival of workers relative to the control diet, indicating the high toxicity of these substances to leaf-cutter ants, with the exception of $0.2 \mathrm{mg}$ of the EE, whose MS $(>25$ days) was not significantly different from that of the control. In addition, the tested concentrations were not dose-dependent, suggesting the high formicidal potential of E. pumila.

The most toxic fractions compared to the control using the log-rank test $(\mathrm{p}<0.05)$ were $2.0 \mathrm{mg}$ of EAF, in which the cumulative mortality was $100 \%$ on day 21 and the MS was 3 days, and $2.0 \mathrm{mg}$ of MF, in which mortality was $98 \%$ on day 25 and MS was 2 days.

The comparison of the toxicity of EAF and $\mathrm{MF}$ indicated that $2.0 \mathrm{mg}$ of EAF was more effective. However, the comparison of these two fractions at $1.0 \mathrm{mg}$ demonstrated that the formicidal activity of MF was higher.

The bioactive substances from the EAF and MF were isolated by chromatography. A mixture of the triterpenes $\alpha$-amyrin (1), $\beta$-amyrin (2), and lupeol (3) was isolated from EAF (Figure 6) whereas the flavonoid rutin (4) was isolated from the MF (Figure 7). 


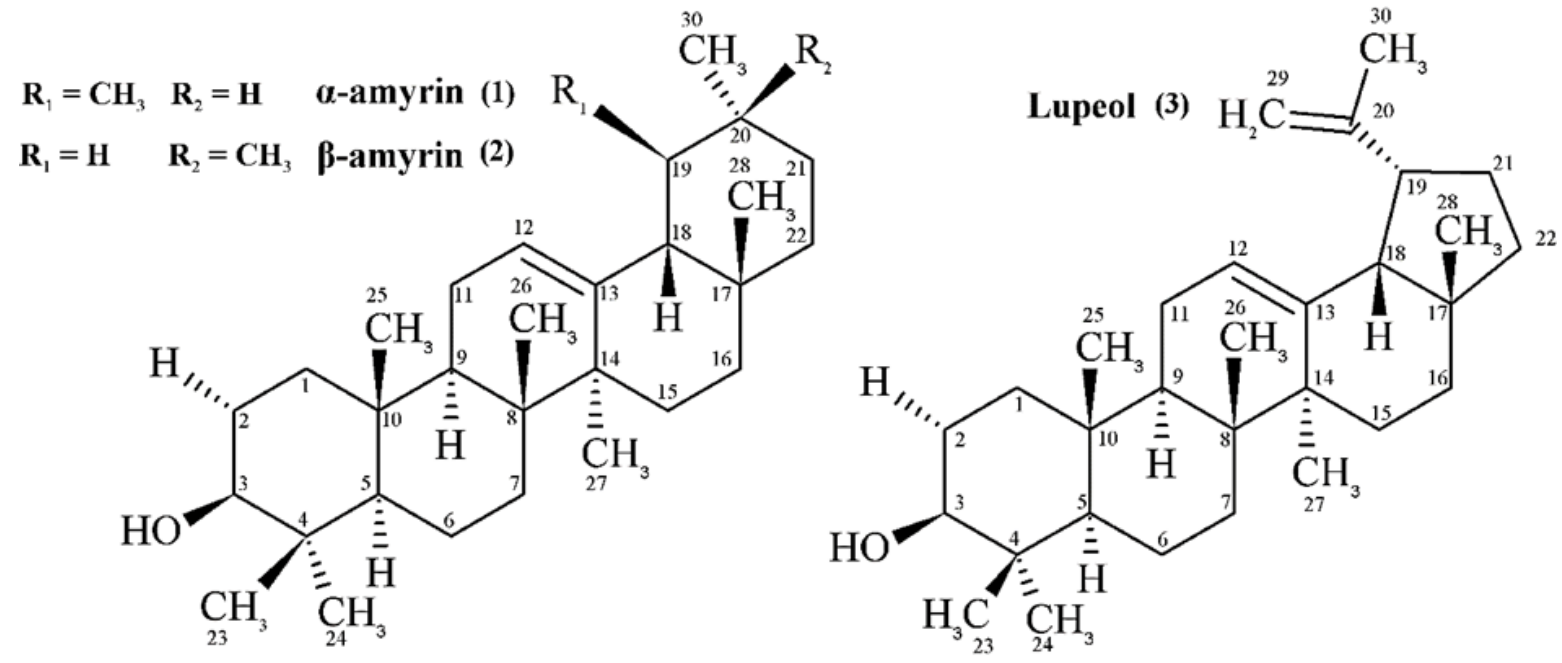

Figure 6. Triterpenes isolated from the leaves of E. pumila.

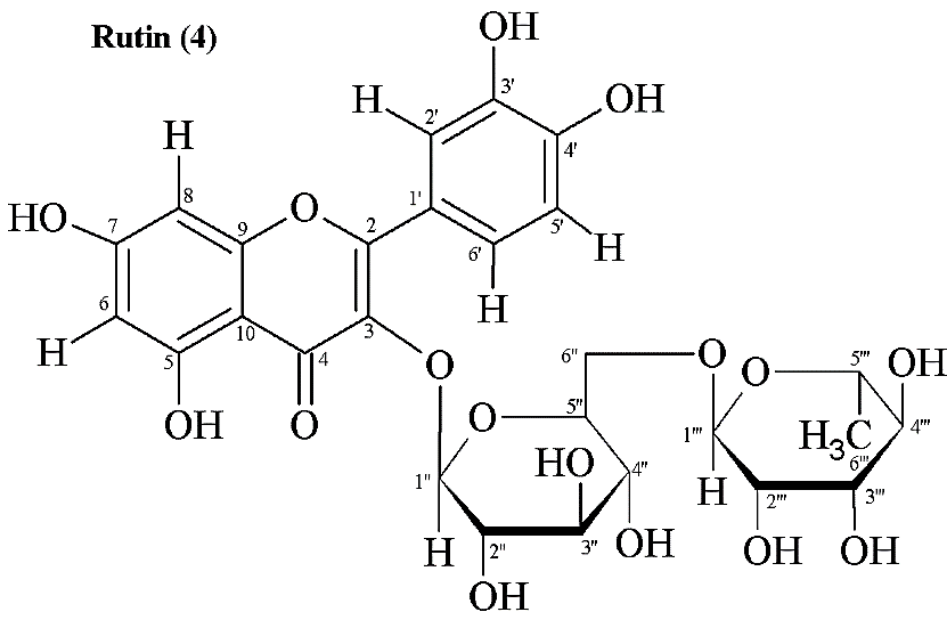

Figure 7. Flavonoid isolated from the leaves of E. pumila.

$\alpha$-amyrin in mixture (1)

White solid. RMN ${ }^{1} \mathrm{H}\left[500 \mathrm{MHz}, \mathrm{CDCl}_{3}\right.$, d (ppm), $J(\mathrm{~Hz})]: 5.12(t, J=3.6 \mathrm{~Hz}, \mathrm{H}-12) ; 3.20(d d, J$ $=4.9 ; 11.4, \mathrm{~Hz}, \mathrm{H}-29) . \mathrm{RMN}{ }^{13} \mathrm{C}\left[125 \mathrm{MHz}, \mathrm{CDCl}_{3}\right.$, $\mathrm{d}(\mathrm{ppm})]: 38.7$ (C-1); 28.7 (C-2); 79.1 (C-3); 38.7 (C -4); 55.2 (C-5); 18.3 (C-6); 31.9 (C-7); 40.0 (C-8); 47.7 (C- 9); 36.6 (C-10); 23.3 (C-11); 124.4 (C-12); 139.5 (C-13); 42.1 (C-14); 27.3 (C-15); 26.6 (C-16); 33.0 (C-17); 59.1 (C-18); 39.6 (C-19); 39.6 (C-20); 31.2 (C-21); 41.5 (C-22); 28.1 (C-23); 15.6 (C-24); 15.6 (C-25); 16.8 (C-26); 23.2 (C-27); 28.1 (C-28); 17.4 (C-29); 21.3 (C-30).

$\beta$-amyrin in mixture (2)

White solid. RMN ${ }^{1} \mathrm{H}\left[500 \mathrm{MHz}, \mathrm{CDCl}_{3}\right.$, d (ppm), J (Hz)]: $5.18(t, J=3.6 \mathrm{~Hz}, \mathrm{H}-12) ; 3.24(d d, J$ $=5.0 ; 11.1, \mathrm{~Hz}, \mathrm{H}-29) . \mathrm{RMN}{ }^{13} \mathrm{C}\left[125 \mathrm{MHz}, \mathrm{CDCl}_{3}\right.$, d (ppm)]: 38.7 (C-1); 27.2 (C-2); 79.0 (C-3); 38.6 (C -4); 55.2 (C-5); 18.4 (C-6); 32.6 (C-7); 39.6 (C-8); 47.6 (C- 9); 36.6 (C-10); 23.5 (C-11); 121.7 (C-12); 145.2 (C-13); 41.7 (C-14); 26.2 (C-15); 26.0 (C-16); 32.8 (C-17); 47.2 (C-18); 46.8 (C-19); 31.2 (C-20); 34.7 (C-21); 37.1 (C-22); 27.9 (C-23); 15.5 (C-24); 15.5 (C-25); 16.8 (C-26); 25.7 (C-27); 28.3 (C-28);
33.3 (C-29); 23.6 (C-30).

White solid. RMN ${ }^{1} \mathrm{H}\left[500 \mathrm{MHz}, \mathrm{CDCl}_{3}\right.$, d (ppm). $J(\mathrm{~Hz})]: 1.68(s, \mathrm{H}-30) ; 4.68(d, J=2.3 \mathrm{~Hz}, \mathrm{H}$ -29); 4.56 (m, H-29). RMN ${ }^{13} \mathrm{C}\left[125 \mathrm{MHz}, \mathrm{CDCl}_{3}\right.$, d (ppm)]: 38.7 (C-1); 27

Lupeol in mixture (3)

.4 (C-2); 79.0 (C-3); 38.8 (C-4); 55.3 (C-5); 18.3 (C-6); 34.3 (C-7); 40.8 (C-8); 50.4 (C- 9); 37.1 (C-10); 20.9 (C-11); 25.1 (C-12); 38.0 (C-13); 42.8 (C-14); 27.4 (C-15); 35.6 (C-16); 43.0 (C-17); 48.3 (C-18); 48.0 (C-19); 150.9 (C-20); 29.6 (C-21); 40.0 (C-22); 27.9 (C-23); 15.3 (C-24); 16.1 (C-25); 16.0 (C-26); 14.1 (C-27); 18.0 (C-28); 109.3 (C-29); 19.3 (C-30).

Rutin (4)

Yellow solid. RMN ${ }^{1} \mathrm{H}[500 \mathrm{MHz}, \mathrm{MeOD}, \mathrm{d}$ (ppm), $J(\mathrm{~Hz})]: 6.11(d, J=2.1 \mathrm{~Hz}, \mathrm{H}-6) ; 6.30(d, J$ $=2.1 \mathrm{~Hz}, \mathrm{H}-8) ; 7.56(d, J=2.1 \mathrm{~Hz}, \mathrm{H}-2$ '); $6.76(d, J$ $=9.0 \mathrm{~Hz}, \mathrm{H}-5$ '); $7.53(d d, J=8.5$ e $J=2.1 \mathrm{~Hz}, \mathrm{H}-$ 6'); $5.01(d, J=7.6 \mathrm{~Hz}, \mathrm{H}-1$ '' $)$; $4.42(d, J=1.2 \mathrm{~Hz}$, $\left.\mathrm{H}-1{ }^{\prime, '}\right) ; 1.01\left(d, J=6.0 \mathrm{~Hz}, \mathrm{H}-6,{ }^{\prime \prime}\right)$. RMN ${ }^{13} \mathrm{C}[125$ $\mathrm{MHz}, \mathrm{MeOD}, \mathrm{d}(\mathrm{ppm})]: 158.0$ (C-2); 134.1 (C-3); 178.0 (C-4); 161.6 (C-5); 98.6 (C-6); 164.6 (C-7); 
93.4 (C-8); 157.1 (C- 9); $104.2(\mathrm{C}-10) ; 122.1\left(\mathrm{C}-1^{\prime}\right)$; 116.3 (C-2'); 144.6 (C-3'); 148.3 (C-4'); 114.6 (C5'); 121.8 (C-6'); 103.3 (C-1'’); 75.8 (C-2'’); 74.3 (C-3'’); 70.0 (C-4'’); 76.8 (C-5'); 67.1 (C-6'); $101.1\left(\mathrm{C}-1{ }^{\prime \prime \prime}\right) ; 70.8$ (C-2','); 70.7 (C-3"',); 72.5 (C4 ,', $) 68.3$ (C-5,',); 16.5 (C-6,',

Salatino et al. (1998) have shown that lupeol, one of the components of the wax of the epicuticle of Didymopanax vinosum (Araliaceae), strongly inhibits the foraging activity of $A$. sexdens rubropilosa, suggesting that the activity of the EAF is due to the lupeol present in this fraction.

Studies have shown that the methanol extract of the leaves of E. pumila and the fraction from which rutin was isolated presented insecticidal activity (KUBO; VIEIRA; FUKUHARA, 1990; KUBO, 1991). Silva et al. (2016) demonstrated that rutin extended the life cycle of larvae and pupae of the caterpillar Spodoptera frugiperda J. E. Smith, 1797 (Lepidoptera: Noctuidae); Guarda et al. (2016) evidenced that a flavonoid was active against Aedes aegypti larvae.

Rutin is used as an insecticide, and the extract of rue (Ruta graveolens), whose active ingredient is a flavonoid, is used to control insects such as aphids and scale insects (BARBOSA; SILVA; CARVALHO, 2006). Rutin is also the most abundant flavonoid of the extract of timbo (Ateleia glazioviana), an efficient formicide of shock action produced and commercialized in Santa Catarina with the name "Citromax" (CANTARELLI et al., 2005).

These results reinforce the possibility of using E. pumila to control $A$. sexdens rubropilosa.

\section{CONCLUSION}

The ethanol extract and the hexane, dichloromethane, and ethyl acetate fractions of Esenbeckia pumila leaves are toxic to Artemia salina, whereas the methanol fraction is not toxic to microcrustaceans.

The extract and fractions presented insecticidal activity against Atta sexdens rubropilosa, especially the ethyl acetate and methanol fractions, which proved to be the most promising and might pave the way for new studies on the isolation and characterization of the compounds from this plant species.

The phytochemical characterization of $E$. pumila allowed isolating the flavonoid rutin and a mixture of the triterpenes $\alpha$-amyrin, $\beta$-amyrin, and lupeol.

\section{ACKNOWLEDGMENTS}

To the Coordination of Improvement of
Higher Education Personnel (Coordenação de Aperfeiçoamento de Pessoal de Nível SuperiorCAPES) for funding this research; to the Federal University of Goiás (Universidade Federal de GoiásUFG), Federal University of Ceará (Universidade Federal do Ceará-UFC), and State University of São Paulo (Universidade Estadual Paulista-UNESP) for technical assistance.

\section{REFERENCES}

ALBUQUERQUE, L. P. et al. Toxic effects of Microgramma vacciniifolia rhizome lectin on Artemia salina, human cells, and the schistosomiasis vector Biomphalaria glabrata. Acta Tropica, v. 138, s/n, p. 23-27, 2014.

ALMEIDA, R. N. A. et al. Toxicity of substances isolated from Helietta puberula RE Fr. (Rutaceae) to the leaf-cutting ant Atta sexdens L. (Hymenoptera: Formicidae) and the symbiotic fungus Leucoagaricus gongylophorus (Singer) Möller BioAssay, v. 2, n. 2, p. 1-8, 2007.

APU, A. S. et al. Antimicrobial activity and brine shrimp lethality bioassay of the leaves extract of Dillenia indica Linn. Journal of Young Pharmacists, v. 2, n. 1, p. 50-53, 2010.

BARBOSA, F. R.; SILVA, C. S. B.; CARVALHO, G. K. L. Uso de inseticidas alternativos no controle de pragas agrícolas. Petrolina, PE: EMBRAPA Semi-Árido, 2006. 47 p. (Embrapa Semi -Árido. Documentos, 191).

BIAVATTI, M. W. et al. Leaf-cutting ants toxicity of limonexic acid and degraded limonoids from Raulinoa echinata. X-Ray Structure of Epoxyfraxinellone. Journal of the Brazilian Chemical Society, v. 16, n. 6, p. 1443-1447, 2005.

BITCHAGNO, G. T. M. et al. Lemairones A and B: Two new antibacterial tetraflavonoids from the leaves of Zanthoxylum lemairei (Rutaceae). Phytochemistry Letters, v. 14, s/n, p. 1-7, 2015.

BUENO, O. C. et al. Sobrevivência de operárias de Atta sexdens rubropilosa Forel (Hymenoptera: Formicidae) isoladas do formigueiro e alimentadas com dietas artificiais. Anais da Sociedade Entomológica do Brasil, v. 26, n. 1, p. 107-113, 1997.

CAMPOS, S. C. et al. Toxicidade de espécies vegetais. Revista Brasileira Plantas Medicinais, v. 18, n. 1, Sup., p. 373-382, 2016.

CANTARELLI, E. B. et al; Efeito de diferentes doses do formicida "Citromax" no controle de 
Acromyrmex lundi (Hymenoptera: Formicidae). Ciência Florestal, v. 15, n. 3, p. 249-253, 2005.

CARDOSO-LOPES, E. M. et al. Alkaloids from stems of Esenbeckia leiocarpa Engl. (Rutaceae) as potential treatment for Alzheimer Disease. Molecules, v. 15, n. 12, p. 9205-9213, 2010.

COY-BARRERA, C. A.; CUCA-SUÁREZ, L. E.; LONDOÑO, C. Q. Revista Cubana de Plantas Medicinales, v. 18, n. 4, p. 638-653, 2013.

CUCA-SUÁREZ, L. E et al Actividad antibacteriana de terpenoides y alcaloides aislados de tres plantas colombianas. Revista Cubana de Farmacia, v. 45, n. 2, p. 275-282, 2011.

DELLA LUCIA, T. M. C.; GANDRA, L. C.; GUEDES, R. N. C. Managing leaf-cutting ants: peculiarities, trends and challenges. Pest Management Science, v. 70, n. 1, p. 14-23, 2014.

DOLABELA, M. F. et al. In vitro antiplasmodial activity of extract and constituents from Esenbeckia febrifuga, a plant traditionally used to treat malária in the Brazilian Amazon. Phytomedicine, v. 15, n. 5, p. $367-372,2008$.

ELANDT-JOHNSON, R. C.; JOHNSON, N. L. Survival models and data analysis. Toronto: Wiley -Interscience, 1980. $457 \mathrm{p}$.

FERNANDES, J. B. et al. Extrações de óleos de sementes de citros e suas atividades sobre a formiga cortadeira Atta sexdens e seu fungo simbionte. Química Nova, v. 25, n. 6, p. 1091-1095, 2002.

GOMES, M. C. A. R. et al. Toxicity of plant extracts from Bahia, Brazil, to Atta sexdens (Hymenoptera: Formicidae) workers. Sociobiology, v. 63, n. 2, p. 770-776, 2016.

GUARDA, C. et al. Atividade larvicida de produtos naturais e avaliação da susceptibilidade ao inseticida Temefós no controle do Aedes aegypti (Diptera: Culicidae). Interciência, v. 41, n. 4, p. 243-247, 2016.

KUBO, I. Recent applications of counter-current chromatography the isolation of bioactive natural products. Journal of Chromatography, v. 538, n. 1, 187-191, 1991.

KUBO, I.; VIEIRA, P. C.; FUKUHARA, K. Efficient isolation of the insect growth inhibitory flavone glycoside rutin from two tropical medicinal plants by Rotation Locular Countercurrent Chromatography (RLCC). Journal of Liquid Chromatography, v. 13, n. 12, p. 2441-2448, 1990.
KUETE, V. et al. Antimicrobial activity of the methanolic extract and compounds from Teclea afzelii (Rutaceae). South African Journal of Botany, v. 74, n. 4, p. 572-576, 2008.

LEITE, J. J. G. et al. Chemical composition, toxicity and larvicidal and antifungal activities of Persea americana (avocado) seed extracts. Revista da Sociedade Brasileira de Medicina Tropical, v. 42, n. 2, p. 110-113, 2009.

MATOS, F. J. A. Introdução à fitoquímica experimental. 3. ed. Fortaleza, CE: UFC, 2009. 150 p.

MEYER, B. N. et al. Brine shrimp: a convenient general bioassay for active plant constituents. Planta Medica, v. 45, n. 5, p. 31-34, 1982.

MOLINA-SALINAS, G. M.; SAID-FERNÁNDEZ, S. A modified microplate cytotoxicity assay with brine shrimp larvae (Artemia salina). Pharmacologyonline, v. 3, s/n, p. 633-638, 2006.

MUGANGA, R. et al. In vitro and in vivo antiplasmodial activity of three Rwandan medicinal plants and identification of their active compounds. Planta Medica, v. 80, n. 6, p. 482-489, 2014.

MUKANDIWA, L.; ELOFF, J. N.; NAIDOO, V. Larvicidal activity of leaf extracts and seselin from Clausena anisata (Rutaceae) against Aedes aegypti. South African Journal of Botany, v. 100, s/n, p. 169-173, 2015.

NAPOLITANO, H. B. et al. Aurapten, a coumarin with growth inhibition against Leishmania major promastigotes. Brazilian Journal of Medical and Biological Research, v. 37, n. 12, p. 1847-1852, 2004.

NGUTA, J. M. et al. Biological screening of Kenya medicinal plants using Artemia salina L. (Artemiidae). Pharmacologyonline, v. 2, s/n, p. 458 $-478,2011$.

NISAR, M. et al. H. Larvicidal, insecticidal, brine shrimp cytotoxicity and anti-oxidant activities of Diospyros kaki (L.) reported from Pakistan. Pakistan Journal of Pharmaceutical Sciences, v. 28, n. 4, p. 1239-1243, 2015.

SILVA, T. R. F. B. et al. Effect of the flavonoid rutin on the biology of Spodoptera frugiperda (Lepidoptera: Noctuidae). Acta Scientiarum. Agronomy, v. 38, n. 2, p. 165-170, 2016.

TEREZAN, A. P. et al. Activities of extracts and compounds from Spiranthera odoratissima St. Hil. (Rutaceae) in leaf-cutting ants and their symbiotic 
fungus. Journal of the Brazilian Chemical Society, v. 21, n. 5 , p. $882-886,2010$.

ZANETTI, R. et al. An overview of integrated management of leaf-cutting ants (Hymenoptera: Formicidae) in brazilian forest plantations. Forests, v. 5, n. 3, p. 439-454, 2014. 